\title{
Erratum: Interactions Between Cadmium and Zinc in the Biological Samples of Pakistani Smokers and Nonsmokers Cardiovascular Disease Patients
}

\section{Hassan Imran Afridi • Tasneem Gul Kazi • Naveed Kazi • Ghulam Abbas Kandhro • Jameel Ahmed Baig • Mohammad Khan Jamali • Mohammad Balal Arain • Abdul Qadir Shah}

\section{Erratum to: Biol Trace Elem Res \\ DOI 10.1007/s12011-009-8607-3}

The original version of this article unfortunately contained mistakes.

In table 2 , the units of white blood cell count and platelet count should be $\mathrm{K} / \mathrm{mm}^{3}$, while $\mathrm{M} / \mathrm{mm}^{3}$ for red blood cell count.

The online version of the original article can be found at http://dx.doi.org/10.1007/s12011-009-8607-3.

H. I. Afridi • T. G. Kazi $(\bowtie) \cdot N$. Kazi • G. A. Kandhro • J. A. Baig • M. K. Jamali • M. B. Arain • A. Q. Shah National Center of Excellence in Analytical Chemistry, University of Sindh, Jamshoro 76080, Pakistan e-mail: tgkazi@yahoo.com

\section{H. I. Afridi}

e-mail: hassanimranafridi@yahoo.com

N. Kazi

e-mail: tgkazi@yahoo.com

\section{J. A. Baig}

e-mail: jab_mughal@yahoo.com

M. K. Jamali

e-mail: mkhanjamali@yahoo.com

M. B. Arain

e-mail: bilal_ku2004@yahoo.com 